TITLE:

\title{
A NEW SECOND SPECIES OF DIMORPHIC ALCYONACEAN OCTOCORAL MINABEA FROM THE BAYS OF SAGAMI AND SURUGA, WITH THE EMENDATION OF GENERIC DIAGNOSIS
}

\author{
$\operatorname{AUTHOR}(\mathrm{S})$ : \\ Utinomi, Huzio; Imahara, Yukimitsu
}

CITATION:

Utinomi, Huzio ...[et al]. A NEW SECOND SPECIES OF DIMORPHIC ALCYONACEAN OCTOCORAL MINABEA FROM THE BAYS OF SAGAMI AND SURUGA, WITH THE EMENDATION OF GENERIC DIAGNOSIS. PUBLICATIONS OF THE SETO MARINE BIOLOGICAL LABORATORY 1976, 23(3-5): 205-212

\section{ISSUE DATE:}

1976-10-30

URL:

http://hdl.handle.net/2433/175941

RIGHT: 


\title{
A NEW SECOND SPECIES OF DIMORPHIC ALCYONAGEAN OCTOCORAL MINABEA FROM THE BAYS OF SAGAMI AND SURUGA, WITH THE EMENDATION OF GENERIC DIAGNOSIS ${ }^{1,2)}$
}

\author{
HuzIo UTINOMI \\ 2565-27, Chûoh-dai, Sirahama, Wakayama-Ken, Japan \\ and \\ YUKIMITSU IMAHARA \\ Marine Science Museum, Tokai University, Shimizu
}

With Text-figures $1-3$ and Plate $I$

\begin{abstract}
Three alcyoniid specimens had been recorded as a new species Minabea robusta (MS) Utinomi from Sagami Bay (Utinomi, 1962); one specimen of the genus Minabea was later collected from Suruga Bay. Upon closely systematic examination of these specimens from the two bays, they were identified as a single species, Minabea robusta sp. nov. This new octocoral is described in detail. In addition, the generic diagnosis of Minabea is emended.
\end{abstract}

\section{Introduction}

Since the genus Minabea was created by the senior author (H.U.) in the family Alcyoniidae for a monotypic species $M$. ozakii Utinomi from Kii coast (Utinomi, 1957 a), no other species of this genus have been described anywhere in the world.

Recently one alcyoniid specimen collected from Suruga Bay by the junior author (Y.I.) was identified with the specimens reported under the name of $M$. robusta (MS) Utinomi from Sagami Bay (Utinomi, 1962), after he sent a preliminary note on the structure, with figures and photographs of the specimen to the senior author and then confirmed by the latter.

The present species is columnar in appearance and has dimorphic zooids like the type species, but differs distinctly from the type species in the following features: the genital production within both zooids, and the spiculation of the interior of the capitulum.

On account of these characteristics, the following points of the generic diagnosis are emended: the genital production occurs only within the siphonozooids or within both zooids occurring in the peripheral layer, the cortex contains short-waisted capstans, the interior contains similarly larger double heads with a short waist or

1) Contributions from the Seto Marine Biological Laboratory, No. 623.

2) Contributions from the Marine Science Museum, Tokai University, No. 35.

Publ. Seto Mar. Biol. Lab., XXIII (3/5), 205-212, 1976.

(Article 15) 
slender rods.

As the senior author pointed out (Utinomi, 1957a), the type-species M. ozakii belongs to the group of deep-water forms in the subfamily Anthomastinae. The present species is certainly referred to the same group by the color and growth form of the colony. However, it was collected from rather shallow-water. Furthermore, no alcyoniid specimen containing the gonads within both zooids has not been found. This newly found second species of Minabea provides an interesting problem as to the speciation among the alcyoniid group to clarify their status.

The senior author (H.U.) wishes here to express deepest gratitude to His Majesty the Emperor and His staff in the Biological Laboratory of the Imperial Household, Tokyo for giving a privilege to study on the precious specimens concerned among His vast collections taken from the Sagami Bay from time to time.

The junior author (Y.I.) extends special thanks to Prof. S. Motoda, Faculty of Marine Science and Technology, Tokai University, and Associate Prof. K. Suzuki, Marine Science Museum of the same university, for their guidance and generosity in conducting the littoral benthic survey around the Uchiura coast of the Suruga Bay and in speculating in alcyonarian research at their laboratory.

\section{Descriptions}

\section{Family Alcyoniidae Lamouroux, 1812}

\section{Genus Minabea Utinomi, 1957}

Minabea Utinomi, 1957a, p. 139.

Generic Diagnosis: Fleshy alcyoniid of unbranched, digitate or columnar capitulum, arising from a short sterile stalk spreading over other object. Dimorphic zooids on all sides of capitulum; autozooids large, non-spiculiferous, completely retractile; siphonozooids small, in minute verrucae; both zooids or only siphonozooids containing gonads within. Sclerites of cortex of stalk and capitulum are short-waisted capstans or spindles; interior contains slender rods or short-waisted capstans (doubleheads). (Emended herein).

Type Species: Minabea ozakii Utinomi, 1957.

\section{Minabea robusta sp. nov.}

Japanese name: Oo-minabetosaka, nom. nov.

Material Examined: (1) Three specimens from Taine, off Hayama, $25 \mathrm{~m}$ deep in Sagami Bay. 26-VII-1929. (Holotype, BLIH-Coel. No. 50A; paratype, BLIHCoel. No. 50B, C). (2) One specimen from Uchiura coast, $30 \mathrm{~m}$ deep in Suruga Bay. 11-VI-1975. (Paratype, MSM-INV-75-048).

Measurement (in Millimeters): (1) Holotype (50A) and paratype specimens (50B, C) from Sagami Bay. Longtime preserved condition, so that rather contracted in 
situ.

$\begin{array}{lccc} & 50 \mathrm{~A} & 50 \mathrm{~B} & 50 \mathrm{C} \\ \text { Length } & 71 & 65 & 57 \\ \text { (Capitulum+stalk) } & (55+16) & (43+20) & (40+17) \\ \text { Diameter (tip, middle, base) } & 11,20,31 & 16,24,29 & 15,30,32\end{array}$

(2) Paratype specimen (MSM-INV-75-048) from Suruga Bay. Somewhat fresh condition.

$\begin{array}{lrcr}\text { Length (Capitulum+stalk) } & 170 & (145+25) & \\ \text { Diameter (tip, middle, base) } & 23 & 45 & 35 \times 45\end{array}$

External Appearance: Unbranched, digitate or columnar robust colony with dimorphic zooids. The colony consists of a long columnar capitulum and a short sterile stalk, about one-eighth of the total height. All the specimens from Sagami Bay are in a rather contracted state in alcohol, all zooids being completely withdrawn within the coenenchyme. However, one specimen, which was recently collected from Suruga Bay, holds a fresh state, even when preserved in alcohol, and is a slightly extended condition, so that the following description is largely based on this new paratype specimen.

The surface layer of the capitulum is covered with a number of small low verrucae of siphonozooids, with many autozooidal calyces, fewer in number, between the siphonozooidal verrucae. The diameter of the autozooidal calyces is about 1.4$2.5 \mathrm{~mm}$, and of the siphonozooidal verrucae about $0.4-0.7 \mathrm{~mm}$. The interval between every two autozooids is not definite.

The autozooids are completely retractile; when extended, they reach about 7 $\mathrm{mm}$ in length excluding tentacles. The tentacles are slender, and about $2.6 \mathrm{~mm}$ long when extended. The tentacles possess 15-17 filiform pinnules on each side. The pinnules in the middle and distal part are long (about $0.3 \mathrm{~mm}$ ), but the $5-6$ proximal ones are much shorter (about $0.1 \mathrm{~mm}$ ).

Internal Canal System and Genital Products: In the transverse and longitudinal sections of the distal part of the capitulum, there are several broad sac-like autozooidal gastric cavities and narrow, minute elliptical siphonozooidal cavities. These two kind of cavities are arranged in 1-3 rows in the outer layer of the coenenchyme. There are many medullar canals, smaller than the autozooidal cavities but larger than the siphonozooidal cavities in diameter, arranged in the inner region, and the thickness of the medullar canals at the center of the capitulum is similar to that of the autozooids.

In the middle part of the capitulum, the autozooidal and medullar cavities are similar in size.

In the sterile stalk, these cavities in the outer layer, one-fourth of the diameter, are narrower than those in the inner layer.

The gastric cavities of the both zooids distinctly bear 8 mesenteries.

Every autozooidal cavity carries some ripe gonads, and a few ripe gonads are connected to the siphonozooidal cavities. 

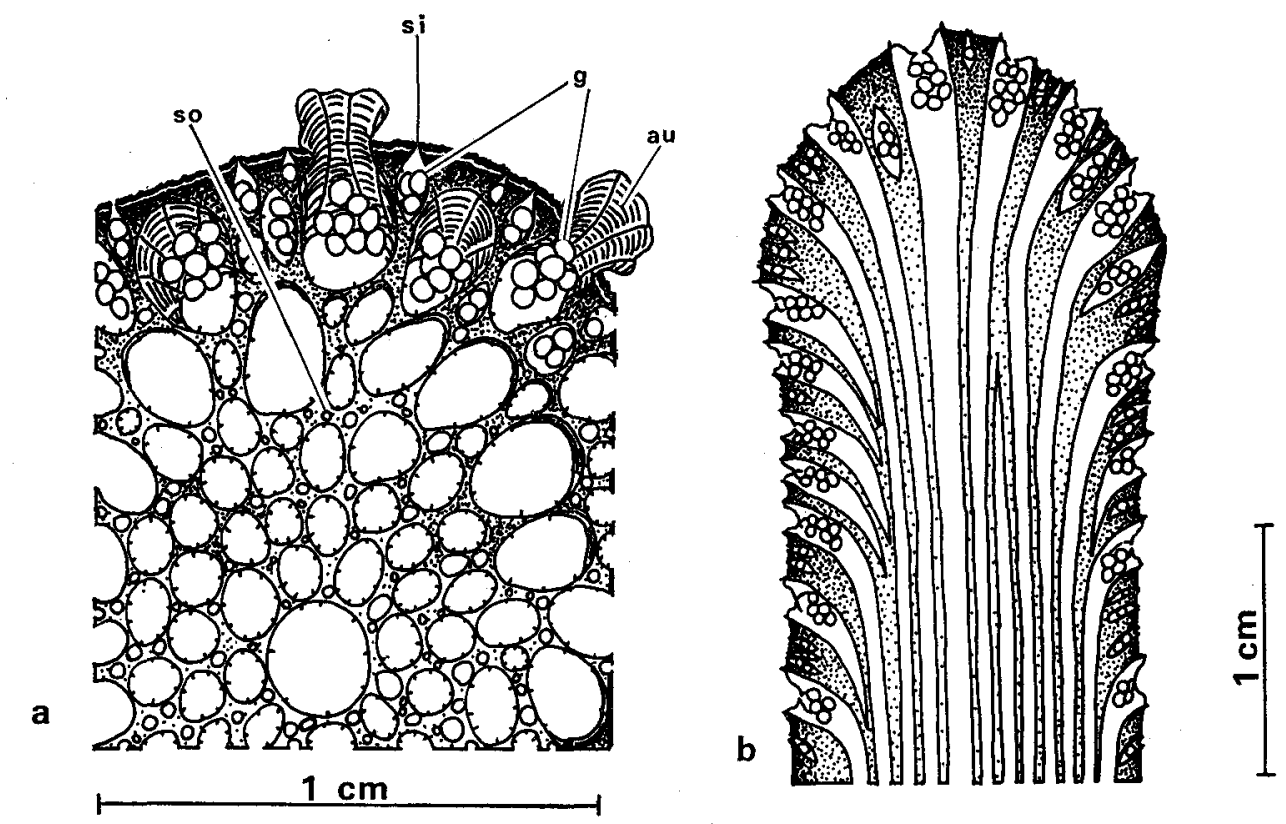

Text-fig. 1. Minabea robusta sp. nov. a, transverse section of the upper part of the capitulum, showing gonads (g) within both siphonozooids (si) and autozooids (au), central canal of the primary polyp, and soleniae (so). b, longitudinal section of the distal part of the capitulum. $(\mathrm{a}, \times 5 ; \mathrm{b}, \times 2.5)$

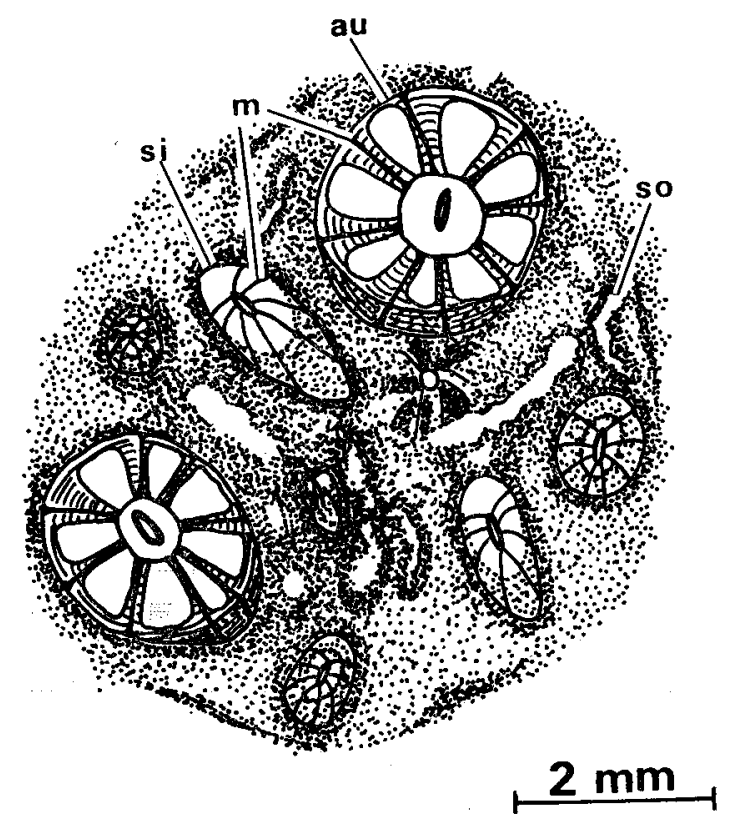

Text-fig. 2. Minabea robusta sp. nov. A structure under cortex of the capitulum, showing 8 mesenteries $(\mathrm{m})$ of the both siphonozooids (si) and autozooids (au), and soleniae (so). ( $\times 10)$ 
In an oblique section parallel with the autozooidal cavities in the upper part of the capitulum, many fine soleniae linking all the cavities are clearly found.

Spiculation: The autozooid is completely free from sclerites.

The cortex of the capitulum contains a number of small tuberculate capstans, with a short waist or crosses $(0.058 \times 0.068-0.058 \times 0.082 \mathrm{~mm})$. The cortex of the sterile stalk contains abundant short-waisted double-heads like those of the capitulum cortex in appearance but somewhat smaller $(0.036 \times 0.045-0.046 \times 0.058 \mathrm{~mm})$. These spicules are densely set.
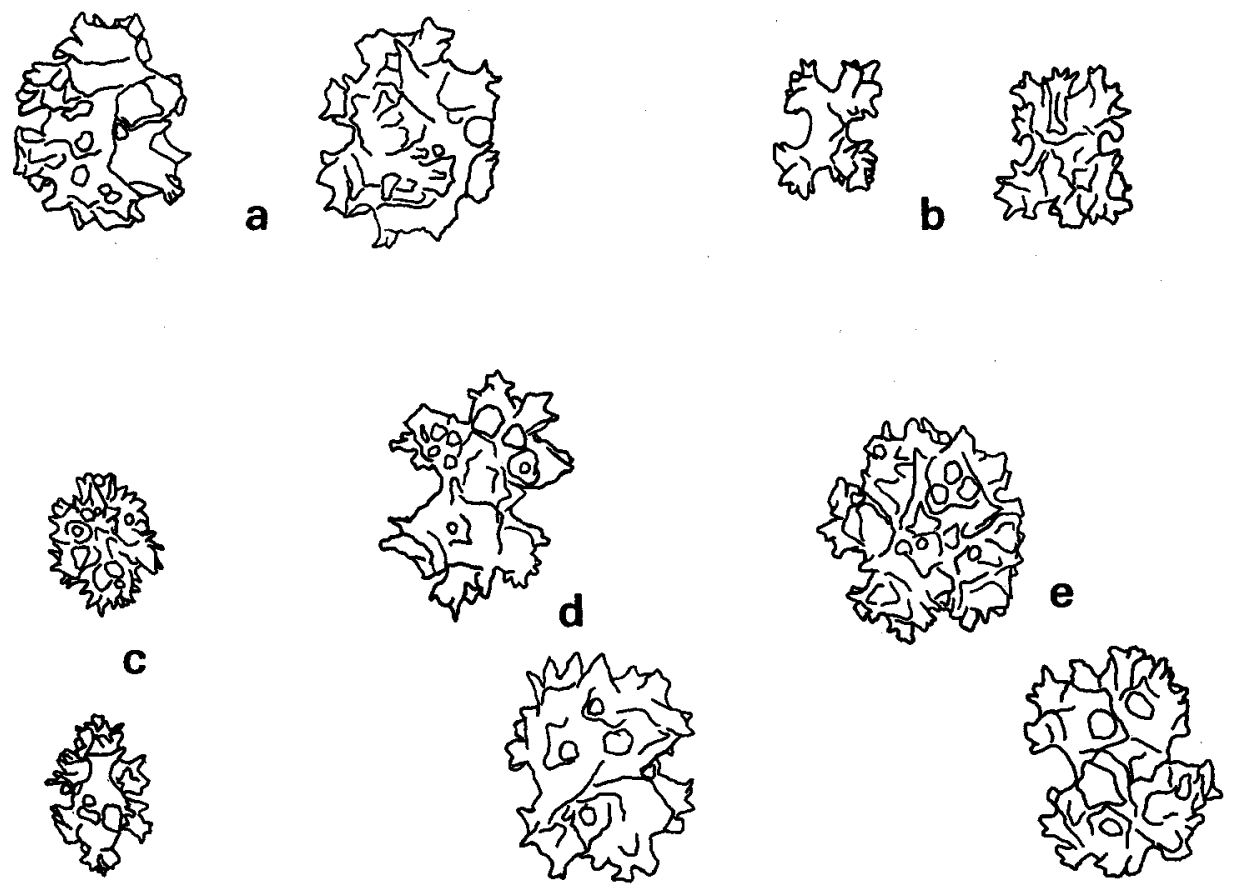

Text-fig. 3. Minabea robusta sp. nov. Spicules of: a, cortex of the capitulum; b, cortex of the sterile stalk; c, calyx and verruca; $d$, canal walls of the capitulum; $e$, canal walls of the sterile stalk. $(\times 135)$

The calyx and verruca are densely packed with small waisted capstans (about $0.035 \times 0.050 \mathrm{~mm}$ ).

In the canal walls of both the capitulum and stalk, there are some capstans resembling capitulum cortex spicules $(0.060 \times 0.068-0.070 \times 0.082 \mathrm{~mm})$.

Such knobby rod-like sclerites as seen in the type species $M$. ozakii Utinomi (1957a) and Anthomastus phalloides Benham (1928) are not found at all in the interior.

The number of the spicules decreases toward the center of the capitulum.

Coloration: The coloration in alcohol preserved state is quite similar to that in life. The capitulum is light yellow-orange, while the calyx of the autozooids and the verruca of the siphonozooid are chrome yellow to light reddish yellow. The sterile stalk is pink to light orange, and the whole autozooid is translucent white. 
The spicules of the calyx and verruca are reddish yellow to translucent white. All of the other spicules are reddish yellow to translucent white.

\section{Systematic Discussion}

The present species differs distinctly from the monotypic species $M$. ozakii Utinomi, in the following points: smaller gastric cavity of the siphonozooid, the presence of the genital production within both zooids, the capstan-typed sclerites in the capitulum interior, and occurring in the shallower habitat.

The siphonozooidal cavity of the present species is more minute and shorter, lying in only the outermost layer of the coenenchyme, whereas that of the typespecies $(M$. ozakii) is rather large and extending to the inner layer. The indistinct demarcation between autozooidal cavities and medullar canals of the present species does not conform with $M$. ozakii Utinomi indicating that the species bears close relationship to the Scleraxonian families Briareidae and Paragorgiidae in this canal system (Utinomi, 1957a). The medullar canals extend downwards, especially the central canal of the primary polyp and the several other innermost canals, which are not narrowed and extend to the base of the colony, as in the allied monomorphic genus Bellonella (Kükenthal, 1906; Utinomi, 1957b, 1958).

The siphonozooids, on the other hand, possess 8 complete mesenteries somewhat resembling those of Anthomastus (Kükenthal, 1906, 1910; Nutting, 1912; Molander, 1915; Verrill, 1922; Jungersen, 1927; Benham, 1928; Bock, 1938) and of Carotalcyon (Utinomi, 1952).

The ripe gonads within both zooids have never been known in any species or genera in the family Alcyoniidae, as well as the family Xeniidae, even in the dimorphic forms (Hickson, 1895, 1931; Pratt, 1903, 1905; Cylkowski, 1911; Gohar, 1940).

In the spiculation, the present species does not contain the slender rods which are packed in the coenenchyme in $M$. ozakii Utinomi. In connection with this it should be noticed that most of the genus Anthomastus have spindle- or needle-like sclerites in the interior (e.g. Nutting, 1912; Bayer, 1952), while a species A. granulosus Kükenthal has tuberculate capstans only (Kükenthal, 1910; Utinomi, 1960). Although Utinomi (1957a) stated that Minabea and Anthomastus are in a close relationship with each other, if the above mentioned feature of the spiculation is considered as an important generic character, such close relationship will be broken down in this single point.

As to the habitat, the type-species was obtained from the depth ranging 120-270 $\mathrm{m}$ (Utinomi, 1957a, 1960), while the present species was obtained from the depth range of 25-30 m. In this respect alone, the former clearly belongs to the deepwater group of the subfamily Anthomastinae in which the colony is vividly colored red to orange and rather simple monocentric in growth form, with comparatively well developed siphonozooids (Utinomi, 1957a). The latter belongs to the same group in its growth form and color of the colony, but occurs in somewhat shallower water, as most of dimorphic alcyoniids growing in the tropical and subtropical seas. 
The genus Minabea consisting of a Bellonella-like long polypiferous columnar capitulum and a short sterile stalk, is dimorphic alcyonacean octocoral, adapted to shallower environment than Anthomastus and its allies.

For the reasons discussed above, Anthomastus phalloides Benham (1928) from New Zealand (including $A$. agilis Tixier-Durivault, 1970 from New Caledonia as a probable synonym) should be transferred to the genus Minabea.

Among the monomorphic genera in the Alcyonacea, this genus comes the nearest to the genus Bellonella morphologically.

In conclusion, it seems clear that there is no direct correlation between the polyp dimorphism and the formation of genital products in the essential significance, since the emvironmental condition around their habitats in the Octocorallia may affect on their sexual reproduction to the greater or less extent, in connection with the developing degree of zooids.

Accordingly, such familial or subfamilial differentiation in the classification as proposed by Verrill (1922) and Bock (1938) cannot be taken into account for the time being.

\section{REFERENGES}

Bayer, F.M. 1952. Descriptions and redescriptions of the Hawaiian octocorals collected by the U.S. Fish Commission steamer "Albatross". (1. Alcyonacea, Stolonifera, and Telestacea.) Pacific Sci., 6(2): 126-136, figs. 1-8.

Benham, W.B. 1928. On some alcyonarians from New Zealand waters. Trans. N.Z. Inst., 59(1): 67-84, figs. 1-31.

Bock, S. 1938. The alcyonarian genus Bathyalcyon. Kungl. Svenska Vetens.-Akad. Handl., ser. 3, 16(5): 1-54, pls. 1-2.

Cylkowski, B. 1911. Untersuchungen über den Dimorphismus bei den Alcyonarien. Inaug.-Diss., Univ. Breslau. 1-48, pls. 1-7.

Deichmann, E. 1936. The Alcyonaria of the western part of the Atlantic Ocean. Mem. Comp. Zool., Harvard Coll., 53: 1-317, pls. 1-37.

Gohar, A.F. 1940. Studies on the Xeniidae of the Red Sea. Publ. Mar. Biol. Sta. Ghardaqa (Red Sea), 2: 23-118, pls. 1-7.

Hickson, S.J. 1895. The anatomy of Alcyonium digitatum. Quart. J. micr. Sci., N.S., 37(4): 343-388, pls. 36-39.

— 1904. The Alcyonaria of the Cape of Good Hope. Part II. Mar. Invest. South Africa, 3: $211-239$, pls. 7-9.

1930. On the classification of the Alcyonaria. Proc. Zool. Soc. Lond., 1930(15): 229-252.

1931. The alcyonarian family Xeniidae. With a revision of the genera and species. Great Barr. Reef Exped. Sci. Rep, 4(5): 137-179, pl. 1.

Jungersen, H.F.E. 1927. Anthomastus. Danish Ingolf-Exped., 5(11): 1-14, pl. 1. Copenhagen.

Kükenthal, W. 1906. Alcyonacea. Wiss. Ergebn. Deutsch. Tiefsee-Exped., 13(1): 1-111, pls. 1-12. Jena.

- 1910. Zur Kenntnis der Gattung Anthomastus Verr. Math.-Phys. Klasse de Bayer. Akad. der Wiss. Abhandl. Suppl., 1(9): 1-15, pl. 1. München.

Molander, A.R. 1915. Northern and arctic invertebrates in the collection of the Swedish State Museum (Riksmuseum). VII. Alcyonacea. Kungl. Svenska Vetenskaps-Akad. Handl., 51(11): 1-94, pls. $1-3$.

Nutting, C.C. 1912. Description of the Alcyonaria collected by the U.S. Fisheries steamer "Albatross", mainly in Japanese waters, during 1906. Proc. U.S. Natl. Mus., 43(1923): 1-104, pls. 1-21. 
Pratt, E.M. 1903. The Alcyonaria of the Maldives. Part II. The genera Sarcophytum, Lobophytum, Sclerophytum and Alcyonium. In: J.S. Gardiner (ed.) Fauna and Geography of the Maldive and Laccadive Archipelagoes, 2(1): 503-539, pls. 28-31. London.

1905. The digestive organs of the Alcyonaria and their relation to the mesogloeal cell plexus. Quart. J. micr. Sci., 49(11): 327-362, pls. 20-22.

Studer, Th. 1901. Alcyonaries provenant des campagnes de l'Hirondelle (1886-1888). Rés. Ciamp. Sci. Monaco, 20: 1-64, pls. 1-11. Monaco.

Thomson, J.A. 1927. Alcyonaires provenant des campagnes scientifiques du Prince Albert I de Monaco. Ibid., 73: 1-77, pls. 1-6. Monaco.

Thomson, J. St. 1910. The Alcyonaria of the Cape of Good Hope and Natal. Alcyonacea. Trans. Roy. Soc. Edinb., 47(3): 549-589, pls. 1-4.

1921. South African Alcyonacea. Trans. Roy. Soc. South Afr., 9(2): 149-175, pls. 5-6.

Tixier-Durivault, A. 1970. Les octocoralliaires de Nouvelle-Calédonie. Expéd. fr. Réc. Cor. N.C. Org. Fond. Singer-Polignac 1960-1963, 4: 173-350. Paris.

Utinomi, H. 1952. On a new deep-sea alcyonarian from Sagami Bay, Carotalcyon sagamianum n. gen. et n. sp. Annot. Zool. Japon., 25(4): 441-446.

1957a. Minabea ozakii n. gen. et n. sp., a new remarkable alcyonarian type with dimorphic polyps. Jour. Fac. Sci. Hokkaido Univ. Ser. VI, Zool., 13(1-4): 139-146.

- 1957b. The alcyonarian genus Bellonella from Japan, with descriptions of two new species. Publ. Seto Mar. Biol. Lab., 6(2): 147-168, pls. 9-10.

1958. A revision of the genera Nidalia and Bellonella with an emendation of nomenclature and taxonomic definitions for the family Nidaliidae (Octocorallia, Alcyonacea). Bull. Brit. Mus. (Nat. Hist.), Zool., 5 (5): 101-121.

1960. Noteworthy octocorals collected off the southwest coast of Kii Peninsula, middle Japan. Part 1, Stolonifera and Alcyonacea. Ibid., 8(1): 1-26, pls. 1-2.

1962. Preliminary list of octocorals of Sagami Bay deposited in the Biological Laboratory of the Imperial Household. Ibid., 10(1): 105-108.

Verrill, A.E. 1922. Alcyonaria and Actinaria. Rep. Canadian Arctic Exped. 1913-18, 8(G): 3-50, pls. 1-18. Ottawa.

Verseveldt, J. 1940. Studies on Octocorallia of the families Briareidae, Paragorgiidae and Anthothelidae. Temminckia, 5: 1-142.

Versluys, J. 1906. Bathyalcyon robustum nov. gen., nov. spec. Ein neuer Alcyonarier der Siboga-Sammlung. Zool. Anz., 30: 533-549.

\section{EXPLANATION OF PLATE I}

Minabea robusta sp. nov.

Fig. 1. Holotype specimen (from Sagami Bay), BLIH-Coel. No. 50A. $(\times 1)$

Fig. 2. Paratype specimen (from Sagami Bay), BLIH-Coel. No. 50B. $(\times 1)$

Fig. 3. Paratype specimen (from Suruga Bay), MSM-INV-75-048. $(\times 0.5)$

Fig. 4. Transverse section of the specimen from Suruga Bay. $(\times 0.7)$

Fig. 5. Surface of the middle part of capitulum of the above specimen. $(\times 1.5)$ 
Publ. Seto Mar. Biol. Lab., XXIII (3/5), 1976
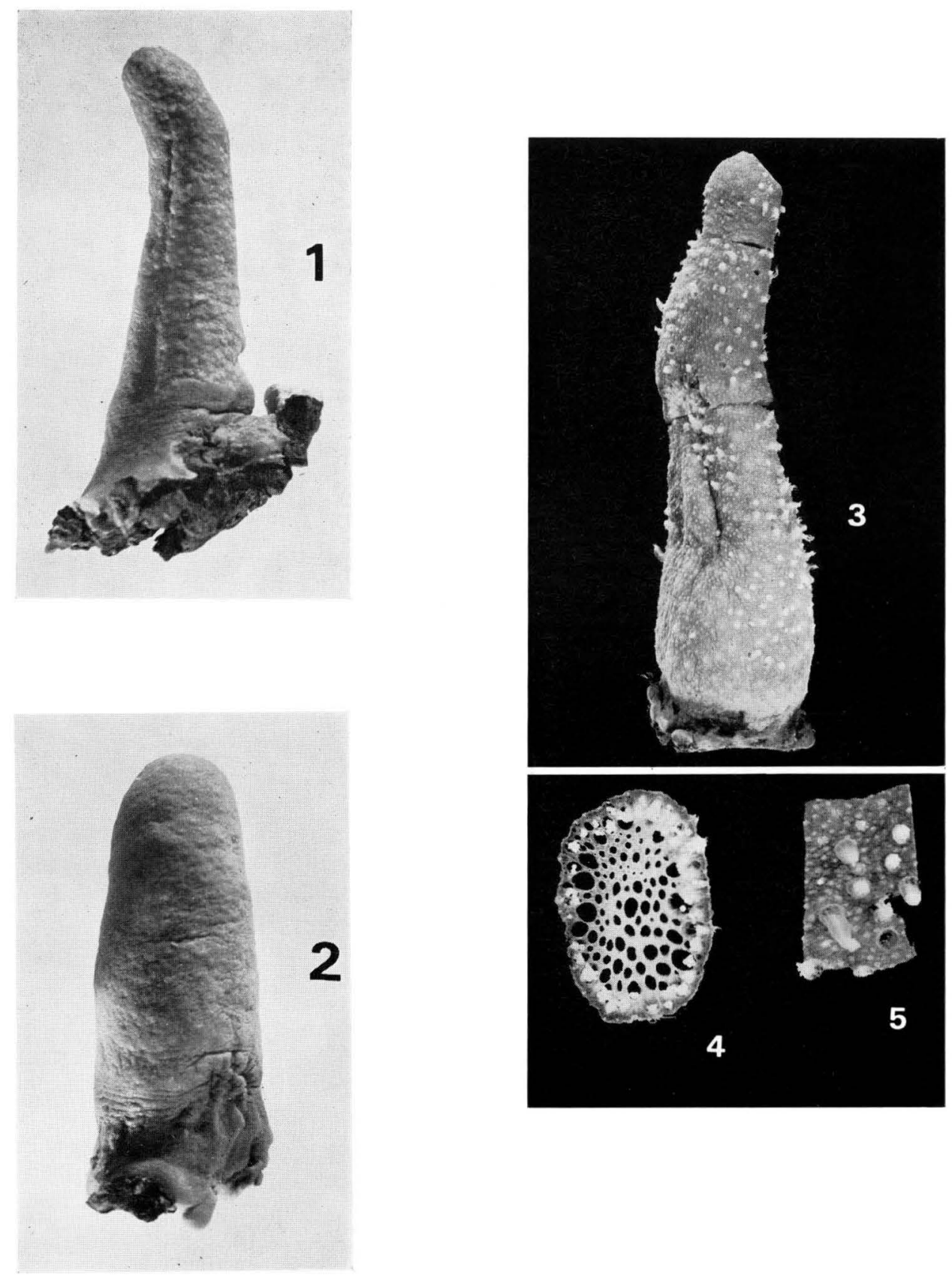

H. Utinomi \& Y. Imahara: The Dimorphic Alcyonacean Minabea 